\title{
Epidemiology and Outcome of Acute Bronchiolitis in Children in the Tobruk Area, Libya
}

\author{
Ghamela S.S.Ali ${ }^{1}$, Hawa H Greish ${ }^{1}$, Fathy .A.A. Abdolmejed ${ }^{2}$ \\ ${ }^{1}$ Pediatric Department, Faculty of Medicine, Tobruk University, Libya \\ ${ }^{2}$ Ophthalmology Department, Faculty of Medicine, Tobruk University, Libya.
}

Received: 14 November 2019/ Accepted: 20 June 2020

Doi: https://doi.org/10.54172/mjsc.v35i1.230

\begin{abstract}
Bronchiolitis is inflammation of the bronchioles, usually caused by an acute viral illness. It is the most common lower respiratory tract infection in children younger than 2 years. The aim of this study is to analyze the hospital incidence of acute bronchiolitis in children aged 2 months up to 2 years, to assess the relation, the severity of the disease to age, gender, season, family history of atopy, and to assess the treatment and outcome. The retrospective study collected the data from the admission records of patients. 198 admissions for acute bronchiolitis represented $14.6 \%$ of hospital admission rates. Most in ages between 2-6 months 128 (64.6\%). Female: Male ratio 1.1:1, female patients $102(51.5 \%)$. The history of Atopy in the family was positive in $136(68.7 \%)$ of patients. The disease was not severe as only $27(13.6 \%)$ were admitted to PICU, and only $3(1.6 \%)$ of them needed mechanical ventilation, in addition to there being no mortalities. Most cases were in winter 81 (40.9\%) (P-value 0.02). All patients received Salbutamol nebulizer, 47 (23.7\%) received hydrocortisone injection (IV), and 45 (22.7\%) received Ipratropium bromide nebulizer. Acute Bronchiolitis is an important cause of admissions in infants, especially under the age of 6 months.
\end{abstract}

Keywords: Acute Bronchiolitis; Incidence; Hospitalization; Tobruk Medical Center-Libya.

\section{INTRODUCTION}

Bronchiolitis is defined as a disorder most commonly caused by a viral infection and is the most common lower respiratory infection in infants (Kliegman et al 2011). Bronchiolitis symptoms and signs include viral upper respiratory Prodrome, followed by breathlessness and wheezing (Ralston et al 2014). Bronchiolitis is often cited as the leading cause of hospitalization for infants and is commonly caused by Respiratory syncytial virus (RSV) (Shay et al 1999; Hasegawa et al 2013, Stockman et al 2012), occurring in epidemics during winter months.

Preterm infants receiving assisted ventilation and those on home oxygen therapy are particularly at risk of RSV related hospitalization (Deshpande \& Northern, 2003, Willson et al 2003). Young maternal age, low social class, low birth weight, and maternal smoking were among factors associated with an increased risk of hospital admission with bronchiolitis (Green et al 2016).

Pre-existing disease/comorbidity, and cardiac anomaly are associated with a significantly higher risk of death from severe RSV infection. Bronchopulmonary dysplasia, immunodeficiency, cerebral palsy, and Down's syndrome are recognized risk factors for severe bronchiolitis (Sommer et al 2011, Boyce et al 2000, Murray et al 2014). Recent studies in the US show the incidence of bronchiolitis hospitalization decreased from 17.9 to 14.9 per 1000 children aged $<2$ years between 2000 and 2009 (Hasegawa et al 2013). In England 2011, the estimated annual hospital admission rate for bronchiolitis was 46.1 per 1000 infants aged $<1$ year (Green et al 2016). In Libya, we 
did not find any published study on national hospitalizations for bronchiolitis.

Aims And Objectives: We aimed to analyze hospital incidence of acute bronchiolitis in children under 2 years of age from Jan 2018 to $31^{\text {st }}$ of Dec 2018. To assess the relationship between acute Bronchiolitis and age, gender, region, and seasonal variation, and the relation to family atopy, and to assess its management and outcomes.

\section{MATERIALS AND METHODS}

A retrospective study was done through the collection of data from the Statistic office. Unfortunately, the International Classification of Disease (ICD) codes is not used in Tobruk medical center. The data was collected from the patient admission files. We have collected the data about the patients who suffered from acute bronchiolitis, aged 2 months up to 2 years old, from January to December 2018. This included the date of admission, date of discharge, gender, age, nationality, residence area, type of admission: PICU or general pediatric ward, family history of Atopy, association with bronchopneumonia, treatment, and mortality.

The primary outcome was the incidence of acute bronchiolitis in children aged 2 months up to 2 years. Secondary outcome measures were: percentage of patients in a different age group between 2 months up to 2 years, percentage of male and female patients, percentage of patients who were admitted to PICU, percentage of use of mechanical ventilation, Strategy of management, Seasonal variation, and relation to Atopy in the family.

Statistics Analysis: Data were expressed in percentages. A frequency table is used to describe the interaction between two categorical variables.

\section{RESULTS}

The total admission of patients in the Pediatric Ward and PICU in the year 2018 was 2999 after excluding the admissions in NICU. From them, 1359 patients were below the age of 2 years, 198 admissions were for acute bronchiolitis in children aged less than 2 years, representing $14.6 \%$ of the hospital admission rate for bronchiolitis per 1000 children aged $<2$ years. In Table 1 we noted, the most age group affected was between 2-6 months 128 (64.6\%) (P-value 0.1). F/M ratio 1.1:1 and female patients $102(51.5 \%)$. The admissions in the general pediatric ward were more than in the Pediatric Intensive Care Unit (PICU) 171 (86.4\%). Only one case admitted to PICU was with Down syndrome and with congenital heart disease $3.7 \%$, and only 3 of 27 (11.1\%) needed mechanical ventilation. The predominance of admissions to PICU was for infants aged 2-6 months 18 (66.7\%) (P-value 0.13) and with male predominance 15 (55.6\%).

We found a significant predominance of the presence of Atopy in the family of patients with acute bronchiolitis 136 (68.7\%). The occurrence of Bronchopneumonia for about a quarter of the patients of $\mathrm{AB} 47$ (23.7\%), that's why they had received antibiotics. The attacks of acute bronchiolitis are at their highest in winter $81(40.9 \%)(\mathrm{P}-$ value 0.02$)$ as seen in Figure 1.

Regarding the management strategy, we found that all patients $198(100 \%)$ have received Salbutamol and IV fluid, 47 (23.7\%) received IV hydrocortisone, and $45(22.7 \%)$ have received Ipratropium bromide nebulizer. 22 (11.1\%) patients have left against medical advice. The predominance of patients of acute bronchiolitis was from Tobruk $162(81.8 \%)$, as seen in Figure 2. Average Length of Stay (LOS) was 3.1-3.3 days, and if primary admission to PICU is needed, then LOS is 4.5 days. The Mortality rate due to acute bronchiolitis in the year 2018 was $0 \%$. 
Table:(1). Characteristics of patients admitted with acute bronchiolitis.

\begin{tabular}{|c|c|c|}
\hline & Number of Children & $\begin{array}{c}\text { Percentage } \\
\%\end{array}$ \\
\hline $\begin{array}{l}\text { Age in months } \\
2-6 \text { months }\end{array}$ & 128 & 64.6 \\
\hline$>6-12$ months & 52 & 26.6 \\
\hline$>12-24$ months & 18 & 9.1 \\
\hline \multicolumn{3}{|l|}{ Gender } \\
\hline Male & 96 & 48.5 \\
\hline Female & 102 & 51.5 \\
\hline \multicolumn{3}{|l|}{$\begin{array}{l}\text { Type of Admis- } \\
\text { sion }\end{array}$} \\
\hline PW & 171 & 86.4 \\
\hline PICU & 27 & 13.6 \\
\hline
\end{tabular}

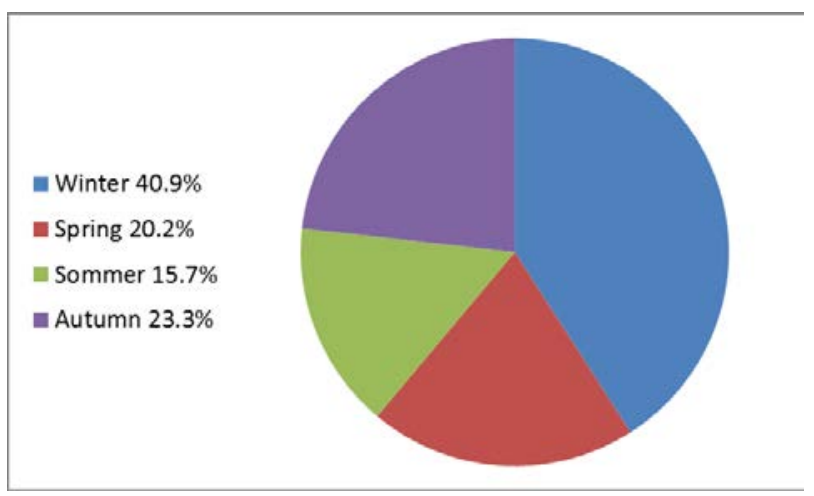

Figure: (1). Distribution of Patients according to Seasonal Variation.

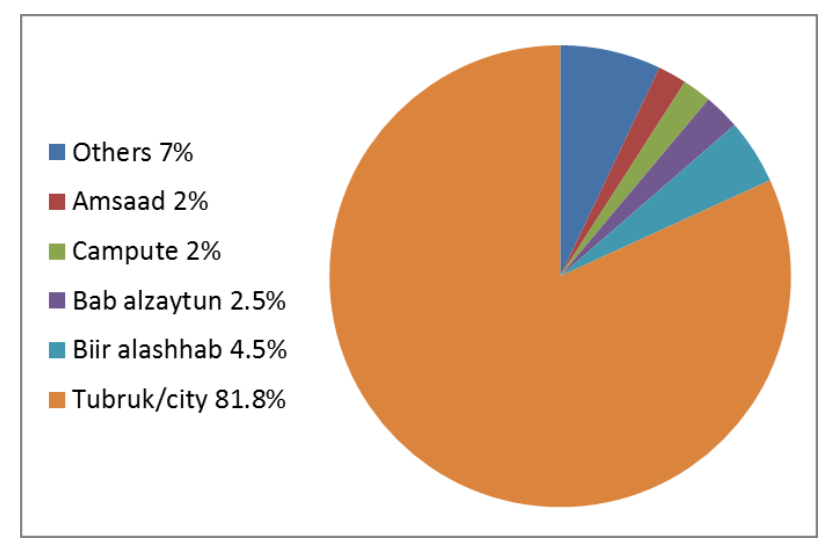

Figure (2).: Distribution of Patients in Urban \& Rural Area

\section{DISCUSSION}

Through this Study, we have recorded 198 admissions for acute bronchiolitis in children aged less than 2 years, representing $14.6 \%$ of the hospital admission rate for bronchiolitis per 1000 children aged $<2$ years after the exclusion of admissions related to routine births. This rate is nearly the same found in research carried out in Portugal during a 16 years study $19.6 \%$ (Mendes-da-Silva et al 2018) and the US between 2000 and $200914.9 \%$ to $17.9 \%$ (Hasegawa et al 2013).

In our study, the predominance was in the age under one year, with a peak age between 2 and 6 months. This is the same result in a study done in Saudi Arabia (Abha city) 1997-2001. In our study, the female patients 102 (51.5\%) are slightly more than male patients with ratio $1.1: 1$, in contrast to a study done in Pakistan and Portugal where there was male predominance (Ahmad et al 2013) (Mendes-da-Silva et al 2018). In our study, most patients had positive Atopy in the family $68.7 \%$, this is the same result reported by Trefny et al (2000). Infants with a family history of Atopy, are at increased risk for severe RSV infection as indicated by higher rates of hospitalization, longer hospital stay, and more frequent occurrences of bronchiolitis (Trefny et al 2000). The patients admitted to PICU were 27 (13.6\%) and were mainly infants aged 2-6 months 18 (66.7\%). These results are the same as those of a study conducted in Saudi Arabia.

The use of mechanical ventilation in our study was $11.1 \%(3 / 27)$. This result is better than in Saudi Arabia, where $50 \%$ of PICU patients needed mechanical ventilation (Al-Shehri et al 2005). 23.7\% of cases were complicated by secondary bacterial infection (Bronchopneumonia), this result was the same in Portugal 27.3\% (Mendes-da-Silva 2018). In our study, the predominance of acute bronchiolitis was in winter. This result was in agreement with that reported by Jeremy et al 2014. The Average Length of Stay (LOS) was 3.1-3.3 days, nearly 
the same as in a study done in Saudi Arabia. Most patients were discharged within 5 days. The mortality rate in our study was $0 \%$ in patients of acute bronchiolitis in the year 2018. The other studies show death from respiratory failure in bronchiolitis is rare and ranges for RSV bronchiolitis from 2.9 (UK) to 5.3 (USA) (Fleming et al 2005, Øymar et al 2014).

\section{CONCLUSION}

The incidence of Acute Bronchiolitis in the Tobruk Area/Libya is nearly the same as the incidence reported in the other Studies.

Based on epidemiology and outcomes made in our study, we conclude that acute bronchiolitis is more prevalent in children younger than one year and patients with a positive family history of Atopy and predominant more in winter. The severe course of the disease was in infants aged less than one year, and in patients with underlying diseases such as Down syndrome and congenital heart disease.

\section{ACKNOWLEDGEMENT}

We would like to thank the workers at the Statistic Office and the Staff of the Pediatric Ward of Tobruk Medical Center.

\section{REFERENCE}

Ahmad, S., Aamir, S., Ahmad, S. (2013). Acute bronchiolitis in children. The Professional Medical Journal, 20(05), 707-712.

Al-Shehri, M. A., Sadeq, A., \& Quli, K. (2005). Bronchiolitis in Abha, Southwest Saudi Arabia: viral etiology and predictors for hospital admission. West African journal of medicine, 24(4), 299-304.

Boyce, T. G., Mellen, B. G., Mitchel Jr, E. F., Wright, P. F., \& Griffin, M. R. (2000). Rates of hospitalization for respiratory syncytial virus infection among children in Medicaid. The Journal of pediatrics, 137(6), 865-870.

Deshpande S., \& Northern V., (2003). The clinical and health economic burden of respiratory syncytial virus disease among children under 2 years of age in a defined geographical area. Arch Dis Child J. 88(12): 1065-106.

Fleming, D. M., Pannell, R. S., \& Cross, K. W. (2005). Mortality in children from influenza and respiratory syncytial virus. Journal of Epidemiology \& Community Health, 59(7), 586-590.

Green, C. A., Yeates, D., Goldacre, A., Sande, C., Parslow, R. C., McShane, P., Pollard, A. J., \& Goldacre, M. J. (2016). Admission to hospital for bronchiolitis in England: trends over five decades, geographical variation and association with perinatal characteristics and subsequent asthma. Archives of disease in childhood, 101(2), 140-146.

Hasegawa, K., Tsugawa, Y., Brown, D. F., Mansbach, J. M., \& Camargo, C. A. (2013). Trends in bronchiolitis hospitalizations in the United States, 20002009. Pediatrics, 132(1), 28-36.

Kliegman, Stanton, ST.Geme, Schor, Behrman (2011). Respiratory System. Nelson Textbook of Pediatrics: 19th ed. 14561459. Elsevier Publication.

Mendes-da-Silva, A., Gonçalves-Pinho, M., Freitas, A., \& Azevedo, I. (2019). Trends in hospitalization for acute bronchiolitis in Portugal: 2000-2015. Pulmonology, 25(3), 154-161.

Murray, J., Bottle, A., Sharland, M., Modi, N., Aylin, P., Majeed, A., Saxena, S., \& Group, M. f. N. I. (2014). Risk factors 
for hospital admission with RSV bronchiolitis in England: a populationbased birth cohort study. PloS one, 9(2), e89186.

Øymar, K., Skjerven, H. O., \& Mikalsen, I. B. (2014). Acute bronchiolitis in infants, a review. Scandinavian journal of trau$m a$, resuscitation and emergency medicine, 22(1), 1-10.

Ralston, SL., Lieberthal, AS., Meissner, HC., et al (2014). Clinical Practice Guideline: The Diagnosis, Management, and Prevention of Bronchiolitis. Pediatrics $\mathrm{J} ; 134(5): 1474-1502$

Shay DK., Holman RC., Newman RD, Liu LL, Stout JW, and Anderson LJ (1999). Bronchiolitis-associated hospitalizations among US children, 19801996. JAMA.;282(15):1440-1446.

Sommer, C., Resch, B., \& Simões, E. A. (2011). Suppl 2: Risk Factors for Severe Respiratory Syncytial Virus Lower Respiratory Tract Infection. The open microbiology journal, 5, 144.

Stockman, L. J., Curns, A. T., Anderson, L. J., \& Fischer-Langley, G. (2012). Respiratory syncytial virus-associated hospitalizations among infants and young children in the United States, 1997-2006. The Pediatric infectious disease journal, 31(1), 59.doi:10.1097/INF.0b013e31822e68e6

Trefny, P., Stricker, T., Baerlocher, C., \& Sennhauser, F. (2000). Family history of atopy and clinical course of RSV infection in ambulatory and hospitalized infants. Pediatric pulmonology, 30(4), 302-306.

Willson, D. F., Landrigan, C. P., Horn, S. D., \& Smout, R. J. (2003). Complications in infants hospitalized for bronchiolitis or respiratory syncytial virus pneumonia. The Journal of pediatrics, 143(5), 142-149. 


\title{
معدل حدوث ونتائج مرض التهاب الثعيبات الهوائية الحاد لاى الأطفال في مدينة طبرق وضواحيها/ليبيا
}

\author{
جميله صالح سعيد علي"*، حواء حمد قريش 1، فتحي عبد الكريم علي عبدالمجيد2 \\ 1"قسم طب الأطفال، كلبه الطب البشري، جامعه طبرق -ليبيا \\ 2قفم طب وجراحة العبيون، كلية الطب البشري، جامعة طبرق، لبييا
}

تاريخ الاستلام: 14 نوفمبر 2019/ تاريخ القبول:2010 يوليو 2020 https://doi.org/10.54172/mjsc.v35i1.230:Doi

الملخص: التهاب الثعيبات الهوائية الحاد هو التهاب الثعيبات الذي يحدث عادة بسبب مرض فيروسي حاد. وهو أكثر عدوى الثي

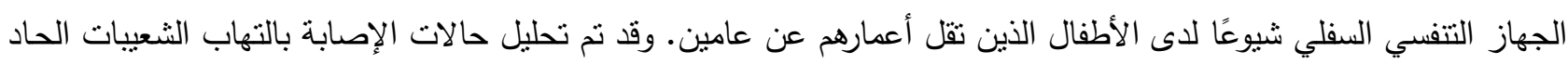
في المسنتفى لدى الأطفال الذين تتراوح أعمارهم بين شهرين حتى سنتين، لتقييم العلاقة بين الإصابة بالاتهاب الثعيبات الهوائية الحساد والعهر والجنس والإقليميـة والتغير الموسـي، والعلاقة بينه وبين وجود امراض حساسية في افراد العائلة، وتقييم العـلاج والنتائج. حيث جمعت الدراسة المعطيات بأنز رجعي من ملفات قبول المرضى. النتائج: 198 حالة دخول لالتهاب الثعيبات الحاد

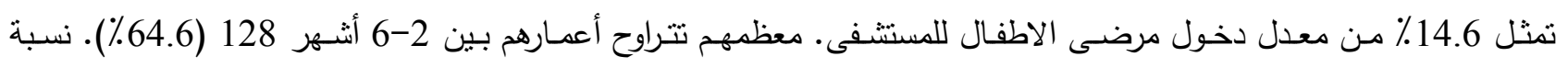
الإناث: للأكور 1.1: 1، والمرضى الإناث 102 (51.5\%). وقد كانت امراض الحساسية في تاريخ العائلة للمرضى منواجدة عند الاغلبية 136 (68.7 \%). لم يكن المرض شديد حيث ان 27 (13.6 \%) هم فقط الذين نم قبولهم في وحدة العناية الفائقة و 3 دنهم

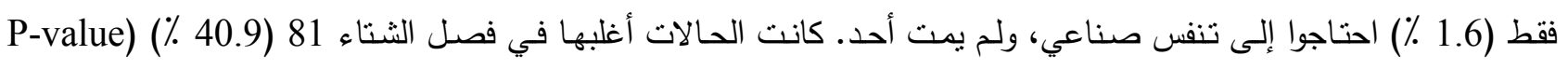
0.02). تلقى جميع المرضى بخار السالبوتامول، وتلقى 47 (23.7 \%) حقن الهيدروكورتيزون في الوريد، وتلقى 45 (22.7 ٪) بخار الإبراتروبيوم. في هذه الدراسة، استتنجنا الآتي: أن التهاب الثعبيات الهوائية الحاد هو سبب مهم لاخول الرضي الرضع وخاصة دون سن 6 أثنهر الى المركز الطبي. الكلمات المفتاحية: التهاب الثعيبات الهوائية الحاد، الإصابة، العلاج في المستشفى، مركز طبرق الطبي - ليبيا 